\title{
Pengaruh Penggunaan Model Pembelajaran Cooperative Tipe Concept Sentence Terhadap Keterampilan Menulis Puisi
}

\author{
Sapti Supriyati ${ }^{1}$,Susan Neni Triani ${ }^{2}$,Wahyuni Oktavia ${ }^{3}$ \\ STKIP Singkawang, Singkawang, Indonesia \\ saptisupriyati09@gmail.com ${ }^{1}$, susannenitriani@gmail.com ${ }^{2}$, oktaviawahyni@gmail.com $^{3}$
}

\author{
Keywords : \\ Cooperative, Concept Centence, \\ Menulis puisi
}

\begin{abstract}
Penelitian ini bertujuan untuk, 1. Mengetahui keterampilan menulis puisi sebelum menggunakan model pembelajaran cooperative tipe concept sentence, 2. Mengetahui keterampilan menulis puisi sesudah menggunakan model pembelajaran cooperative tipe concept sentence, 3. Melihat pengaruh penggunaan model pembelajaran cooperative tipe concept sentence terhadap keterampilan menulis puisi pada siswa kelas VIII D SMP Negeri 20 Singkawang tahun ajaran 2016/2017. Penelitian ini menggunakan metode penelitian eksperimen, menggunakan bentuk Pre Exprimental Design, dan pada penelitian ini digunakan rancangan One-Group Pretest-Posstest Design. Populasi dalam penelitian ini adalah seluruh siswa kelas VIII SMP Negeri 20 Singkawang. Dalam penelitian ini sampel yang diambil menggunakan teknik Purposive Sampling. Penelitian pada tahap pertama atau pretest memperoleh mean sebebsar 68,56. Penelitian pada tahap kedua atau posstest memperoleh mean sebebsar 85,72, hasil mean yang diperoleh sangat berbeda dengan hasil mean yang di dapat pada saat tahap pretest. Berdasarkan hasil uji regresi linear dengan bantuan SPSS versi 17 maka jika nilai sig 0,150 (>) 0,05 dapat dikatakan ada hubungan dalam penggunaan model pembelajaran cooperative tipe concept sentence terhadap hasil belajar siswa. Berdasarkan hasil uji $t$ diperoleh nilai $T_{\text {hitung }}$ lebih besar dati nilai $T_{\text {tabel }}$ yakni 9,020 > 1,710, hal ini dapat di simpulkan bahwa terdapat hubungan nyata antara hasil belajar sebelum dan sesudah digunakannya model pembelajaran cooperative tipe concept sentence. Dengan diperolehnya hasil uji $t$ tersebut maka hipotesis $\mathrm{Ha}$ yang berbunyi pengaruh penggunaan model pembelajaran cooperative tipe concept sentence terhadap hasil belajar menulis puisi diterima.
\end{abstract}

\section{PENDAHULUAN}

Pembelajaran adalah proses interaksi peserta didik dengan pendidik dan sumber belajar pada suatu lingkungan belajar yang meliputi guru dan siswa yang saling bertukar informasi. Kegiatan pembelajaran di sekolah yang dilakukan oleh guru terhadap siswanya selama ini bertujuan untuk meningkatkan aktivitas, mewujudkan dan menghasilkan siswa yang memiliki potensi dalam hal pengetahuan, keterampilan, maupun cara berpikir. Pembelajaran merupakan bantuan yang diberikan pendidik agar dapat terjadi proses pemerolehan ilmu dan pengetahuan, pembentukan sikap dan kepercayaan pada peserta didik. Dengan kata lain, pembelajaran adalah proses untuk membantu peserta didik agar dapat belajar dengan baik. 
Pembelajaran bahasa Indonesia yang baik, diharapkan dapat menghasilkan siswa yang terampil dan menguasai bahasa. Keterampilan siswa dalam berbahasa tidak terlepas dari cara mengajar guru yang baik, suasana kelas yang kondusif, strategi pembelajaran yang tepat, serta keinginan guru untuk selalu memperbaiki pembelajaran. Pada kenyataannya, dalam proses pembelajaran bahasa Indonesia di sekolah-sekolah masih ditemukan para siswa yang belum terampil dan belum menguasai bahasa Indonesia.

Keterampilan menulis merupakan salah satu jenis keterampilan berbahasa yang harus dikuasai siswa. Keterampilan menulis merupakan kemampuan mengungkapkan gagasan, pendapat, dan perasaan kepada pihak lain dengan melalui bahasa tulis. Ketepatan pengungkapan gagasan harus juga didukung dengan ketepatan bahasa yang digunakan Keterampilan menulis adalah menurunkan atau melukiskan lambang-lambang grafik yang menggambarkan suatu bahasa yang dipahami oleh seseorang, sehingga orang-orang lain dapat membaca lambang-lambang grafik tersebut kalau mereka memahami bahasa dan gambaran grafik itu (Tarigan, 2008: 22)". Sejalan dengan pendapat tersebut, menurut Semi (2007: 14) "Menulis merupakan suatu proses kreatif memindahkan gagasan ke dalam lambang-lambang tulisan. Melalui keterampilan menulis, siswa dapat mengungkapkan gagasan, pikiran,dan perasaannya dengan baik dan terbuka, sehingga siswa dapat mengungkapkan perasaan dan pikirannya secara tidak langsung melalui menulis, seperti sebuah karangan yaitu puisi.

Menulis salah satu bagian dari empat aspek keterampilan berbahasa yang selalu dipelajari di sekolah, bahkan menulis salah satu aspek keterampilan berbahasa yang sangat sulit dipelajari, karena dalam aspek menulis siswa dituntut untuk menuangkan ide ke dalam bentuk tulisan, menulis juga dapat bertujuan untuk menginformasikan, dan mengekspresikan ide yang ada di dalam pikiran siswa. Semua mata pelajaran yang dipelajari siswa di sekolah tidak lepas dari kegiatan menulis.

Berdasarkan wawancara yang dilakukan peneliti dengan guru bahasa Indonesia di SMP Negeri 20 Singkawang menunjukkan bahwa kemampuan siswa dalam menulis, khususnya menulis puisi sangat kurang. Dari hasil wawancara yang dilakukan peneliti diperoleh data hasil belajar siswa dalam menulis puisi pada kelas VIII A mencapai ketuntasan 82\%, kelas VIII B 75,34\%, kelas VIII C 70,25\%, kelas VIII D 63,47 \%, dari nilai kriteria ketuntasan minimum yang ditentukan sekolah yaitu 75. Jika dilihat dari hasil belajar siswa pada tiap kelas maka kelas VIII D merupakan kelas yang terendah dalam pencapaian hasil belajar. Oleh karena itu kegagalan yang berwujud rendahnya hasil belajar menulis dipengaruhi oleh faktor tertentu, salah satu faktornya adalah pembiasaan dalam penggunaan model pembelajaran konvensional dalam pembelajaran, lingkungan belajar yang kurang kondusif, dan karakteristik siswa tersebut.

Dari data pengamatan proses dan hasil belajar di kelas VIII D SMP Negeri 20 Singkawang menunjukkan bahwa pembelajaran menulis puisi perlu ditingkatkan. Hal ini bertujuan agar siswa mampu menuangkan ide dan gagasannya ke dalam bentuk tulisan, khususnya dalam menulis puisi dengan model pembelajaran concept sentence, sehingga keterampilan menulis puisi siswa dapat meningkat. Menurut Huda (2014: 315) "Concept sentence merupakan strategi pembelajaran yang dilakukan dengan memberikan kartu-kartu yang berisi beberapa kata kunci kepada siswa, kemudian kata kunci-kata kunci tersebut disusun menjadi beberapa kalimat dan dikembangkan menjadi paragrafparagraf". Peneliti memilih model pembelajaran cooperative tipe concept sentence berdasarkan pertimbangan yang matang, hal ini dikarenakan model pembelajaran cooperative tipe concept sentence memiliki keunggulan dalam meningkatkan hasil belajar. Berdasarkan penjelasan yang telah dikemukakan di atas, maka peneliti tertarik untuk mengangkat masalah mengenai pengaruh penggunaan model pembelajaran cooperative tipe concept sentence terhadap keterampilan menulis puisi siswa kelas VIII D SMP Negeri 20 Singkawang tahun ajaran 2016/2017. Peneliti memilih kelas VIII D SMP Negeri 20 Singkawang dikarenakan menurut sumber data yang diperoleh peneliti yaitu dari guru mata pelajaran bahasa Indonesia di kelas, hasil keterampilan menulis siswa sangat kurang dan rata-rata nilai kelas masih di bawah KKM yang seharusnya yaitu 75 , sehingga perlu suatu strategi 
pembelajaran yang tepat untuk meningkatkan hasil belajar tersebut, yaitu dengan penerapan model pembelajaran Cooperative tipe Concept Sentence.

\section{METODE}

Peneliti dalam penelitian ini menggunakan metode penelitian eksperimen. Menurut Sugiyono (2012: 107), metode penelitian eksperimen adalah metode penelitian yang digunakan untuk mencari pengaruh perlakuan tertentu terhadap yang lain dalam kondisi terkendalikan. Sedangkan menurut Mahmud (2011: 106) "Metode eksperimen adalah satu-satunya metode penelitian yang dianggap paling tepat untuk menguji hipotesis mengenai hubungan sebab akibat. Penelitian ini menggunakan bentuk Pre Exprimental Design, karena peneliti tidak dapat mengontrol dan memanipulasi semua variabel yang relevan antara lain tingkat kecerdasan siswa dan latar belakang siswa atau keadaan sosial ekonomi siswa. Pada penelitian ini digunakan rancang One-Group Pretest-Posttest Design.Sugiyono (2012: 110-111) menerangkan rancangan penelitian dengan One-Group Pretest-Posttest Design, hasil perlakuan dapat diketahui lebih akurat, karena dapat membandingkan dengan keadaan sebelum diberi perlakuan. Dengan demikian perlakuan dapat diketahui lebih akurat, karena dapat membandingkan keadaan sebelum diberi perlakuan. Adapun populasi dalam penelitian ini adalah seluruh siswa kelas VIII SMP Negeri 20 Singkawang.Populasi siswa kelas VIII dalam penelitian ini Siswa kelas yaitu kelas VIII D berjumlah 25 orang yang terdiri dari laki-laki 16 orang dan perempuan 9 orang, sehingga penelitian ini merupakan penelitian sampel. adapun teknik pengumpulan data yang digunakandalam penelitian ini yaitu teknik observasi langsung, teknik pengukuran, dan teknik dokumenter.

Teknik observasi langsung yaitu suatu cara dalam mendapatkan data yang akurat melalui pengamatan secara langsung di dalam kelas dengan membuat daftar observasi. Nawawi (2007: 94) "Teknik observasi langsung adalah cara pengumpulan data yang dilakukan melalui pengamatan dan pencatatan gejala-gejala yang tampak pada objek penelitian yang pelaksanaannya langsung pada tempat dimana suatu peristiwa, keadaan, atau situasi yang sedang terjadi”. Artinya: observasi adalah studi yang disengaja dan sistematis dengan menggunakan (alat indera) mata tentang kejadian secara spontan.

Menurut Arikunto (2013:266)data yang dapat digunakan dalam penelitian dapat dibedakan menjadi tiga jenis, yaitu : Fakta, pendapat, dan kemampuan. Untuk mengukur ada atau tidaknya serta besarnya kemampuan objek yang diteliti, digunakan tes. Khusus untuk tes prestasi belajar yang biasa digunakan disekolah dapat dibedakan menjadi dua, yaitu: tes buatan guru, dan tes terstandar. Tes buatan guru yang disusun oleh guru dengan prosedur tertentu. Atau tes yang belum mengalami uji coba berkalikali. Tes terstandar (standardizwd test), yaitu tes yang biasanya sudah tersedia di lembaga testing, yang sudah terjamin keampuhannya. Atau test yang sudah mengalami uji coba berkali-kali.

Teknik dokumenter adalah teknik pengumpulan data dengan cara mengumpulkan dokumen yang mendukung dalam penelitian. Nawawi (2007:94) menyatakan bahwa: "Teknik dokumenter yaitu cara mengumpulkan data melalui dokumen tertulis, foto, catatan-catatan". Dalam hal ini dokumenter yang akan dianalisis adalah perangkat pembelajaran yang disusun oleh guru mata pelajaran bahasa Indonesia untuk kelas VIII D Sekolah Menengah Pertama Negeri 20 Singkawang.

\section{HASIL DAN PEMBAHASAN}

Tujuan dari penelitian ini adalah untuk mengetahui pengaruh penggunaan model pembelajaran cooperative tipe concept sentence dalam hasil belajar menulis puisi. Berdasarkan analis data yang dilakukan membuktikan bahwa dalam penelitian yang dilakukan memberikan suatu hasil yang postif. Hal ini dibuktikan dengan hasil belajar yang diperoleh dari pretest dan posttest. Hasil pretest yang diperoleh menunjukan rata-rata sebasar 68,56 dan hasil posttest yang diperoleh menunjukan rata-rata sebesar 85,72. Dengan hasil yang didapat maka dapat disimpulkan bahwa penggunaan model 
pembelajaran cooperative tipe concept sentence memberikan pengaruh yang positif dalam proses pembelajaran menulis puisi.

Pelaksanaan penelitian pada tahap pertama atau pretest memperoleh mean sebesar 68,56 . Dengan demikian dapat disimpulkan bahwa hasil belajar siswa sebelum diberikan perlakuan, dalam penggunaan model pembelajaran cooperative tipe concept sentence pada kelas eksperimen tidak memberikan hasil peningkatan yang signifikan. Oleh karena tanpa penggunaan model pembelajaran cooperative tipe concept sentence dalam pembelajaran menulis puisi secara teori belum memberikan pengaruh terhadap hasil belajar pada kelas eksperimen.

Pelaksanaan penelitian pada tahap kedua atau posttest memperoleh mean sebesar 85,72 hasil mean yang diperoleh sangat berbeda dengan hasil mean yang didapat pada saat tahap pretest. Dengan demikian dapat disimpulkan bahwa hasil belajar siswa sesudah diberikan perlakuan, Berdasarkan hasil uji regresi linear dengan bantuan SPSS versi 17 maka jika nilai sig 0,150 (>) 0,05 dapatdikatakan ada hubungan dalam penggunaan model pembelajaran cooperative tipe concept sentence terhadap hasil belajar siswa. Jadi dapat disimpulkan bahwa dari hasil uji regresi linear sederhana dengan bantuan SPSS versi 17 menyatakan ada hubungan antara penggunaan model pembelajaran cooperative tipe concept sentence dengan hasil belajar siswa menulis puisi, dengan kata lain Ha yang berbunyi adanya pengaruh penggunaan model pembelajaran cooperative tipe concept sentence terhadap hasil belajar siswa dalam menulis puisi diterima dan Ho yang berbunyi tidak adanya pengaruh penggunaan model pembelajaran cooperative tipe concept sentence terhadap hasil belajar siswa dalam menulis puisi ditolak.

Berdasarkan hasil uji $t$ diperoleh nilai $\mathrm{T}_{\text {hitung }}$ lebih besar dari nilai $\mathrm{T}_{\text {tabel }}$ yakni 9,020 > 1,710, hal ini dapat disimpulkan bahwa terdapat hubungan nyata antara hasil belajar siswa sebelum dan sesudah digunakannya model pembelajaran cooperative tipe concept sentence.

\section{KESIMPULAN DAN SARAN}

Berdasarkan hasil uji $t$ diperoleh nilai $T_{\text {hitung }}$ lebih besar dari nilai $T_{\text {tabel }}$ yakni 9,020 > 1,710, hal ini dapat disimpulkan bahwa terdapat hubungan nyata antara hasil belajar siswa sebelum dan sesudah digunakannya model pembelajaran cooperative tipe concept centence. Dengan diperolehnya hasil uji $\mathrm{t}$ tersebut maka hipotesis Ha yang berbunyi adanya pengaruh penggunaan model pembelajaran cooperative tipe concept sentence terhadap hasil belajar menulis puisi diterima. Berdasarkan hasil penelitian yang diperoleh maka dapat disimpulkan sebagai berikut. 1) Keterampilan menulis puisi pada siswa kelas VIII D SMP Negeri 20 Singkawang tahun ajaran 2016/2017 sebelum menggunakan model pembelajaran cooperative tipe concept sentence pada tahap pertama atau pretest memperoleh mean sebesar 68,56. 2) Keterampilan menulis puisi pada siswa kelas VIII D SMP Negeri 20 Singkawang tahun ajaran 2016/2017 sesudah menggunakan model pembelajaran cooperative tipe concept sentence pada tahap kedua atau posttest memperoleh mean sebesar 85,72. 3) Terdapat pengaruh penggunaan model pembelajaran cooperative tipe concept sentence terhadap keterampilan menulis puisi pada siswa kelas VIII D SMP Negeri 20 Singkawang berdasarkan hasil uji-t bahwa $\mathrm{T}_{\text {hitung }}$ lebih besar dari $\mathrm{T}_{\text {tabel }}$ yakni 9,020 $>1,710$.

\section{DAFTAR PUSTAKA}

Arikunto, Suharsimi. 2013. Prosedur Penelitian Suatu Pendekatan Praktik. Jakarta: Rineka Cipta.

Huda, Miftahul. 2014. Cooperative Learning. Yogyakarta:Pustaka Pelajar.

Nawawi, Hadari. (2007). Metode Penelitian Bidang Sosial. Yogyakarta: Gajah Mada University Press. 
Journal of Educational Review and Research

Vol. 2 No. 2, December 2019: 112 - 116

REVIEW AND RESEARCH

e-ISSN: 2597-9760, p-ISSN: 2597-9752

Semi, Atar. 2007. Dasar-dasar Keterampilan Menulis. Bandung: Angkasa.

Sugiyono. (2012). Metode Penelitian Kuantitatif, Kualitatif dan $R \& D$. Bandung: Alfabeta.

Tarigan, Henry Guntur. 2008. Menulis sebagai suatu Keterampilan Berbahasa.

Bandung: Angkasa. 